\title{
Front Matter: Volume 9389
}

, "Front Matter: Volume 9389," Proc. SPIE 9389, Next-Generation Optical Communication: Components, Sub-Systems, and Systems IV, 938901 (7 February 2015); doi: 10.1117/12.2185481

SPIE. Event: SPIE OPTO, 2015, San Francisco, California, United States 


\title{
PROCEEDINGS OF SPIE
}

\section{Next-Generation Optical Communication: Components, Sub-Systems, and Systems IV}

\author{
Guifang Li \\ Xiang Zhou \\ Editors
}

10-12 February 2015

San Francisco, California, United States

Sponsored and Published by

SPIE 
The papers included in this volume were part of the technical conference cited on the cover and title page. Papers were selected and subject to review by the editors and conference program committee. Some conference presentations may not be available for publication. The papers published in these proceedings reflect the work and thoughts of the authors and are published herein as submitted. The publisher is not responsible for the validity of the information or for any outcomes resulting from reliance thereon.

Please use the following format to cite material from this book:

Author(s), "Title of Paper," in Next-Generation Optical Communication: Components, Sub-Systems, and Systems IV, edited by Guifang Li, Xiang Zhou, Proceedings of SPIE Vol. 9389 (SPIE, Bellingham, WA, 2015) Article CID Number.

ISSN: 0277-786X

ISBN: 9781628414790

Published by

SPIE

P.O. Box 10, Bellingham, Washington 98227-0010 USA

Telephone +1 3606763290 (Pacific Time) · Fax +1 3606471445

SPIE.org

Copyright (C) 2015, Society of Photo-Optical Instrumentation Engineers.

Copying of material in this book for internal or personal use, or for the internal or personal use of specific clients, beyond the fair use provisions granted by the U.S. Copyright Law is authorized by SPIE subject to payment of copying fees. The Transactional Reporting Service base fee for this volume is $\$ 18.00$ per article (or portion thereof), which should be paid directly to the Copyright Clearance Center (CCC), 222 Rosewood Drive, Danvers, MA 01923. Payment may also be made electronically through CCC Online at copyright.com. Other copying for republication, resale, advertising or promotion, or any form of systematic or multiple reproduction of any material in this book is prohibited except with permission in writing from the publisher. The CCC fee code is 0277-786X/15/\$18.00.

Printed in the United States of America.

Publication of record for individual papers is online in the SPIE Digital Library.

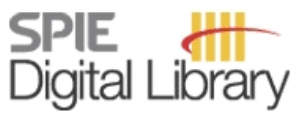

SPIEDigitalLibrary.org

Paper Numbering: Proceedings of SPIE follow an e-First publication model, with papers published first online and then in print. Papers are published as they are submitted and meet publication criteria. A unique citation identifier (CID) number is assigned to each article at the time of the first publication. Utilization of CIDs allows articles to be fully citable as soon as they are published online, and connects the same identifier to all online, print, and electronic versions of the publication. SPIE uses a six-digit CID article numbering system in which:

- The first four digits correspond to the SPIE volume number.

- The last two digits indicate publication order within the volume using a Base 36 numbering

system employing both numerals and letters. These two-number sets start with 00, 01, 02, 03, 04, $05,06,07,08,09,0 A, 0 B \ldots$. OZ, followed by 10-1Z, 20-2Z, etc.

The CID Number appears on each page of the manuscript. The complete citation is used on the first page, and an abbreviated version on subsequent pages. 


\section{Contents}

$\begin{aligned} \vee & \text { Authors } \\ \text { vii } & \text { Conference Committee }\end{aligned}$

MULTIDIMENSIONAL MULTIPLEXING TECHNOLOGIES FOR ADVANCED OPTICAL NETWORKS: JOINT SESSION WITH CONFERENCE 9388

938903 Key technologies for energy and spectral efficient flexible optical networks (Invited Paper) [9389-2]

SDM COMPONENTS

938905 Multicore fiber-based mode multiplexer/demultiplexer (Invited Paper) [9389-4]

938906 Spatial mode rotator based on mechanically-induced twist and bending in few-mode fibers [9389-5]

\section{OPTICAL SIGNAL PROCESSING}

9389 OA Six mode multi-plane light converter for mode-selective spatial multiplexing [9389-9]

ENABLING TECHNOLOGY FOR NEXT-GEN NETWORKS

9389 OB Roles of spectral and spatial aggregation in optical network scaling (Invited Paper) [9389-10]

9389 OC Densely packed NxN wavelength cross-connect switch module [9389-11]

9389 OD Ultra-stable optical amplifier technologies for dynamic optical switching networks [9389-12]

\section{ADVANCED COMPONENTS AND COHERENT SYSTEMS}

9389 OF Investigation of receiver contraints on the transmission performance of 1 Tbps WDM-Nyquist and CO-OFDM signals [9389-14]

9389 OG Advanced unrepeatered systems using novel Raman amplification schemes (Invited Paper) [9389-15]

$9389 \mathrm{OH}$ Parallel and simultaneous spatial mode conversion using photorefractive crystal for photonic cross-connect [9389-16] 
ADVANCED MODULATION AND DSP

9389 ol Nonlinear compensation technologies for future optical communication systems (Invited Paper) [9389-17]

9389 OJ Optical OFDM signal generation using integrated-optic multiplexer based on optical IFFT [9389-18]

9389 OK DSP-based optical modulation technique for long-haul transmission (Invited Paper) [9389-19]

9389 OL Offset-16QAM-based coherent WDM with multi-carrier group detection [9389-20]

SDM COMPONENTS, SYSTEMS, AND NETWORKS

9389 ON Rapid measurement of the fiber's transmission matrix [9389-22]

938900 Determination of the physical fiber modes [9389-24]

\section{COHERENT DETECTION AND ACCESS NETWORK}

9389 OP Coherent detection in self-homodyne systems with single and multi-core transmission (Invited Paper) [9389-25]

\section{POSTER SESSION}

9389 OS Photodiodes integration on a suspended ridge structure VOA using 2-step flip-chip bonding method [9389-28]

9389 0T Ageing of fiber optical devices [9389-29] 


\section{Authors}

Numbers in the index correspond to the last two digits of the six-digit citation identifier (CID) article numbering system used in Proceedings of SPIE. The first four digits reflect the volume number. Base 36 numbering is employed for the last two digits and indicates the order of articles within the volume. Numbers start with 00, 01, 02, 03, 04, 05, 06, 07, 08, 09, OA, OB...0Z, followed by 10-1Z, 20-2Z, etc.

Arik, Sercan Ö., OB

Awaji, Yoshinari, OD, OP

Barré, Nicolas, OA

Bednarek, Lukas, OT

Brüning, Robert, $0 \mathrm{~N}, 00$

Bunsen, Masatoshi, $\mathrm{OH}$

Burtsev, Sergey, OG

Chang, Do-il, OG

Cincotti, Gabriella, 03

Denolle, Bertrand, OA

Dou, Liang, 0 I

Duparré, Michael, 0N, 00

Fevrier, Herve, OG

Flamm, Daniel, ON, $0 \mathrm{O}$

Forbes, Andrew, ON

Fu, Songnian, 06, OL

Genevaux, Philippe, OA

Goto, Ryuichiro, 05

Hirasaki, Yuki, OH

Ho, Keang Po, OB

Hoshida, Takeshi, 01

Hraghi, Abir, OF

Ikeda, Kazuhiko, OC

Jian, Pu, OA

Kahn, Joseph M., OB

Kanno, Atsushi, OP

Kawanishi, Tetsuya, OP

Kawashima, Hitoshi, OC

$\mathrm{Ki}$, Hyun Chul, OS

Kim, Doo Gun, OS

Kim, Hwe Jong, OS

Kim, Seon Hoon, OS

Kim, Tae Un, OS

Klaus, Werner, OP

Koudelka, Petr, OT

Labroille, Guillaume, OA

Latal, Jan, OT

Lee, Dong Yeol, OS

Lenz, Julian, 00

Lim, Jung Woon, OS

Liu, Deming, 06, OL

Luís, Ruben S., OP

Lukas, Luise, 00

Maeda, Tomohiro, $\mathrm{OH}$

Man, R., OD

Marcinka, Ondrej, OT

Matsuo, Shoichiro, 05

Mendinueta, José-Manuel Delgado, OP

Menif, Mourad, OF

Miwa, Takaaki, oJ
Morizur, Jean-François, OA

Nakashima, Hisao, Ol

Ngcobo, Sandile S., ON

Nishimoto, Shoko, 05

Oda, Shoichiro, 0 I

Okamoto, Atsushi, $\mathrm{OH}$

Omichi, Koji, 05

Oyama, Tomofumi, 0 l

Park, Chul Hee, OS

Pelouch, Wayne, OG

Perrier, Philippe, OG

Pinel, Olivier, OA

Puttnam, Benjamin J., OD, OP

Rasmussen, Jens C., 01

Saitoh, Kunimasa, 05

Sakaguchi, Jun, OP

Sasaki, Keiichi, OC

Sasaki, Yusuke, 05

Shahpari, Ali, OP

Shimizu, Satoshi, 03

Shiraiwa, M., OD

Shum, Perry, 06, OL

Siska, Petr, OT

Sorimoto, Keisuke, OC

Sugihara, T., OK

Tachikura, Masao, 0C

Takenaga, Katsuhiro, 05

Takiguchi, Koichi, 0J

Tang, Ming, 06, OL

Tanimura, Takahito, 01

Tao, Zhenning, ol

Teixeira, Antonio, $\mathrm{OP}$

Tomita, Akihisa, $\mathrm{OH}$

Tsang, K. S., OD

Tsuda, Hiroyuki, OC

Uematsu, Takui, 05

Uemura, Hitoshi, 05

Uetsuka, Hisato, 0C

Uto, K., OK

Vasinek, Vladimír, OT

Vujičić, Zoran, OP

Wada, Naoya, 03, OD, OP

Xiang, Meng, OL

Yamashita, Yuto, 0C

Yamauchi, Tomohiro, $\mathrm{Ol}$

Yoshida, T., OK

Yu, Dawei, 06

Zhao, Yanfeng, $\mathrm{OH}$

Zhao, Ying, $\mathrm{Ol}$ 
Proc. of SPIE Vol. $9389938901-6$

Downloaded From: https://www.spiedigitallibrary.org/conference-proceedings-of-spie on 26 Apr 2023 Terms of Use: https://www.spiedigitallibrary.org/terms-of-use 


\section{Conference Committee}

Symposium Chairs

David L. Andrews, University of East Anglia (United Kingdom)

Alexei L. Glebov, OptiGrate Corporation (United States)

Symposium Co-chairs

Jean-Emmanuel Broquin, IMEP-LAHC (France)

Shibin Jiang, AdValue Photonics, Inc. (United States)

Program Track Chair

Benjamin B. Dingel, Nasfine Photonics, Inc. (United States)

Conference Chairs

Guifang Li, CREOL, The College of Optics and Photonics, University of Central Florida (United States)

Xiang Zhou, Google (United States)

Conference Program Committee

Yi Cai, ZTE USA (United States)

Gabriella Cincotti, Università degli Studi di Roma Tre (Italy)

Benjamin B. Dingel, Nasfine Photonics, Inc. (United States)

John D. Downie, Corning Incorporated (United States)

Ronald Freund, Fraunhofer-Institut für Nachrichtentechnik

Heinrich-Hertz-Institut (Germany)

Takahiro Kodama, Mitsubishi Electric Corporation (Japan)

Shoichiro Matsuo, Fujikura Ltd. (Japan)

Zhongqi Pan, University of Lovisiana at Lafayette (United States)

Jayanta K. Sahu, University of Southampton (United Kingdom)

Kunimasa Saitoh, Hokkaido University (Japan)

Mark Shtaif, Tel Aviv University (Israel)

Atul K. Srivastava, NEL America, Inc. (United States)

Junqiang Sun, Huazhong University of Science and Technology (China) and Wuhan National Laboratory for Optoelectronics (China)

Fatih Yaman, NEC Laboratories America, Inc. (United States)

Xinliang Zhang, Wuhan National Laboratories for Optoelectronics (China) 


\section{Session Chairs}

1 Optical Communication Plenary Session: Joint Session with Conferences 9387, 9388 and 9390

Guifang Li, CREOL, The College of Optics and Photonics, University of Central Florida (United States)

Benjamin B. Dingel, Nasfine Photonics, Inc. (United States)

2 Multidimensional Multiplexing Technologies for Advanced Optical Networks: Joint Session with Conference 9388

Atul K. Srivastava, NEL America, Inc. (United States)

Guifang Li, CREOL, The College of Optics and Photonics, University of Central Florida (United States)

3 Workshop on High-Speed Transport in Datacenters

Akimasa Kaneko, NEL America, Inc. (United States)

Atul K. Srivastava, NEL America, Inc. (United States)

4 Optical Wireless and Advanced Fiber Technologies for Data Center and Access Network: Joint Session with Conferences 9387 and 9390

Benjamin B. Dingel, Nasfine Photonics, Inc. (United States)

Atul K. Srivastava, NEL America, Inc. (United States)

5 SDM Components

Tsuyoshi Konishi, Osaka University (Japan)

6 Optical Signal Processing

Xiang Zhou, Google (United States)

$7 \quad$ Enabling Technology for Next-Gen Networks

Guifang Li, CREOL, The College of Optics and Photonics, University of Central Florida (United States)

8 Advanced Components and Coherent Systems

Kazi S. Abedin, OFS Fitel LLC (United States)

9 Advanced Modulation and DSP

Gregory Raybon, Alcatel-Lucent (United States)

10 SDM Components, Systems, and Networks Xiang Zhou, Google (United States)

11 Coherent Detection and Access Network

Tomofumi Oyama, Fujitsu Laboratories, Ltd. (Japan) 